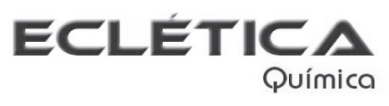

www.scielo.br/eq

Volume 30, número 2, 2005

\title{
Synthesis, characterization and thermal studies of solid state 4-methylbenzylidenepyruvate of some trivalent metal ions
}

\author{
R.A. Mendes, G. Bannach, E.Y. Ionashiro, M. Ionashiro* \\ Instituto de Química, UNESP, CP 355, CEP 14801-970, Araraquara, SP, Brazil \\ "Corresponding author: massaoi@iq.unesp.br
}

\begin{abstract}
Solid state compounds of 4-methylbenzylidenepyruvate with Al(III), Ga(III), In(III) and Sc(III) have been synthesized. Complexometry, X-ray powder diffractometry, infrared spectroscopy and simultaneous thermogravimetry-differential thermal analysis (TG-DTA) have been used to characterize and to study the thermal behavior of these compounds. The results provided information concerning the stoichiometry, crystallinity, thermal stability and thermal decomposition of these compounds.
\end{abstract}

Keywords: 4-methybenzylidenepyruvate; aluminium; gallium; indium; scandium; thermal behaviour.

\section{Introduction}

Several metal-ion complexes of phenyl substituted derivatives of benzylidenepyruvate, $\mathrm{C}_{6} \mathrm{H}_{5}-\mathrm{CH}=\mathrm{CH}_{-} \mathrm{COCOO}^{-}$(BP), have been investigated in aqueous solutions [1-5] and in the solid state [6-13]. In aqueous solutions these works reported the thermodynamic stability $\left(\hat{a}_{1}\right)$ and spectroscopic parameters $\left(\AA_{1 \max }, \ddot{\mathrm{e}}_{1 \max }\right)$, associated with 1:1 complex species, as well as analytical applications of sodium 4-dimethylamino-BP for the gravimetric determination of $\mathrm{Cu}(\mathrm{II})$, and as an indicator in the complexometric titration of Th(IV) an $\mathrm{Al}$ (III), with EDTA. In the solid state, the works reported the synthesis and investigation of the compounds by means of thermogravimetry, derivative thermogravimetry (TG, DTG), differential thermal analysis (DTA), differential scanning calorimetry (DSC), X-ray powder diffractometry, and other methods of analysis. Establishment of stoichiometry and the details of the thermal decomposition were the main purposes of these studies.

In this paper, the object of the present research was to prepare solid state compounds of the $\mathrm{Al}(\mathrm{III}), \mathrm{Ga}(\mathrm{III}), \mathrm{In}(\mathrm{III})$ and $\mathrm{Sc}(\mathrm{III})$ with 4methylbenzilidenepyruvate and to investigate by means of complexometry, X-ray powder diffractometry, infrared spectroscopy and simultaneous thermogravimetry-differential thermal analysis (TG-DTA). The results allowed us to acquire information concerning these compounds in the solid state, including their thermal stability and thermal decomposition.

\section{Experimental}

The sodium salt of 4-methylbenzylidenepyruvic acid was prepared following the same procedure described in the literature [14]. Aqueous solutions of $0.1 \mathrm{M} \mathrm{Na}-4-\mathrm{Me}-\mathrm{BP}$ were prepared by direct weighing of the salt.

Gallium and scandium chloride were prepared from gallium metallic and scandium oxide, respectively, by treatment with concentrated hydrochloric acid. The resulting solutions were evaporated to near dryness, the residues dissolved in distilled water, and the solutions again evaporated to near dryness to eliminate the excess of 
hydrochloric acid. The residues were redissolved in distilled water, transferred to a volumetric flask and diluted in order to obtain ca. $0.1 \mathrm{M}$ solutions. The aqueous solutions of indium and aluminium nitrate were obtained by direct weighing of the respective salts and dissolution in distilled water. The $\mathrm{pH}$ of solutions of aluminium, gallium, indium and scandium were adjusted to $2.0 ; 3.0 ; 3.0$ and 4.0, respectively, by adding diluted sodium hydroxide or hydrochloric acid solutions, and thus prevent the formation of hydroxocomplexes. The $\mathrm{pH}$ of ligand solution was adjusted to 4.0.

The solid state compounds were prepared by adding slowly, with continuous stirring, solution of ligand to the respective metallic ion solution, until total precipitation of the metal ions. The precipitates were washed with distilled water until elimination of the interferent ions, filtered through and dried on Whatman no. 42 filter paper, and kept in a desiccator over anhydrous calcium chloride, under reduced pressure.

In the solid state compounds, hydration water, ligand and metal ion contents were determined from the TG curves. The metal ions were also determined by complexometric titrations with standard EDTA solution, using xylenol orange for gallium, indium and scandium [15] and eriochrome black T, for aluminium as indicator [16].

$\mathrm{X}$-ray powder patterns were obtained by using a Siemens D-500 X-ray diffractometer, employing $\mathrm{Cu}$ Ká radiation ( $\ddot{\mathrm{e}}=1,541 \mathrm{u}$ ) and settings of $40 \mathrm{KV}$ and $20 \mathrm{~mA}$. Infrared spectra for 4-Me-BP compounds, as well as sodium salt, were run on a Nicolet mod. Impact 400 FT-IR instrument, within the $4000-400 \mathrm{~cm}^{-1}$ range. The solid samples were pressed into $\mathrm{KBr}$ pellets.

Simultaneous TG-DTA curves were recorded on a model SDT 2960 thermal analysis system from TA Instruments. The purge gas was an air flow of
$100 \mathrm{~mL} \mathrm{~min}{ }^{-1}$. A heating rate of $20^{\circ} \mathrm{C} \mathrm{min}^{-1}$ was adopted, with samples weighing about 7-8 mg (except of scandium and aluminium, with sample weighing about $4 \mathrm{mg}$ ). Alumina crucibles were used for recording the TG-DTA curves.

\section{Results and discussion}

The analytical results of the synthesized compounds are shown in Table 1. These results permitted to establish the stoichiometry of the compounds, which is in agreement with the general formula $\mathrm{M}(4-\mathrm{Me}-\mathrm{BP})_{3} \cdot \mathrm{nH}_{2} \mathrm{O}$, where $\mathrm{M}$ represents $\mathrm{Al}(\mathrm{III}), \mathrm{Ga}(\mathrm{III}), \mathrm{In}(\mathrm{III})$ or $\mathrm{Sc}(\mathrm{III})$,

4-Me-BP is 4-methylbenzylidenepyruvate and $n$ is 2, 2, 2 and 3, respectively.

The X-ray powder patterns showed that all the compounds were obtained in amorphous state. The amorphous state is related to the low solubility of these compounds.

Infrared spectroscopy data on 4methylbenzylidenepyruvate and its compounds are shown in Table 2. In 4-Me-BP (sodium salt), strong band at $1635 \mathrm{~cm}^{-1}$ and a medium intensity band located at $1408 \mathrm{~cm}^{-1}$ are attributed to the antisymmetrical and symmetrical frequencies of the carboxylate groups, respectively [17,18]. The band centered at $1670 \mathrm{~cm}^{-1}$ is typical of a conjugated ketonic carbonyl group [17, 19]. In the scandium compound the anti-symmetrical stretching carboxylate frequency, as well as that assigned to the ketonic carbonyl, namely 1587 and $1645 \mathrm{~cm}^{-1}$, respectively, are shifted to lower values relative to the corresponding frequencies in 4-Me-BP itself (sodium salt). This behavior indicates that both groups act as coordination centers in the scandium compound [19].

Table 1 - Analytical data for the $\mathrm{ML}_{3} \cdot \mathrm{nH}_{2} \mathrm{O}$

\begin{tabular}{lccccccc}
\hline Compound & \multicolumn{3}{c}{ Metal (\%) } & \multicolumn{3}{c}{ Ligand lost $(\%)$} & \multicolumn{2}{c}{ Water (\%) } \\
\cline { 2 - 8 } & Calcd. & TG & EDTA & Calcd. & TG & Calcd. & TG \\
\hline $\mathrm{AlL}_{3} \cdot 3 \mathrm{H}_{2} \mathrm{O}$ & 4,28 & 4,30 & 4,97 & 86,2 & 86,31 & 5,72 & 5,57 \\
$\mathrm{GaL}_{3} \cdot 2 \mathrm{H}_{2} \mathrm{O}$ & 10,35 & 10,02 & 10,44 & 80,73 & 80,75 & 5,53 & 5,51 \\
$\mathrm{InL}_{3} \cdot 2 \mathrm{H}_{2} \mathrm{O}$ & 15,98 & 16,09 & 15,65 & 74,93 & 75,66 & 5,16 & 5,12 \\
$\mathrm{ScL}_{3} \cdot 3 \mathrm{H}_{2} \mathrm{O}$ & 6,75 & 6,88 & 6,95 & 81,54 & 81,35 & 8,11 & 8,09 \\
\hline
\end{tabular}


Table 2 - Spectroscopic data for sodium 4-methylbenzylidenepyruvate (4-Me-BP) and compounds with some trivalent metal ions ${ }^{\mathrm{a}}$

\begin{tabular}{lccccccc}
\hline Compound & \multicolumn{3}{c}{ Metal (\%) } & \multicolumn{3}{c}{ Ligand lost (\%) } & \multicolumn{2}{c}{ Water (\%) } \\
\cline { 2 - 8 } & Calcd. & TG & EDTA & Calcd. & TG & Calcd. & TG \\
\hline $\mathrm{AlL}_{3} \cdot 3 \mathrm{H}_{2} \mathrm{O}$ & 4,28 & 4,30 & 4,97 & 86,2 & 86,31 & 5,72 & 5,57 \\
$\mathrm{GaL}_{3} \cdot 2 \mathrm{H}_{2} \mathrm{O}$ & 10,35 & 10,02 & 10,44 & 80,73 & 80,75 & 5,53 & 5,51 \\
$\mathrm{InL}_{3} \cdot 2 \mathrm{H}_{2} \mathrm{O}$ & 15,98 & 16,09 & 15,65 & 74,93 & 75,66 & 5,16 & 5,12 \\
$\mathrm{ScL}_{3} \cdot 3 \mathrm{H}_{2} \mathrm{O}$ & 6,75 & 6,88 & 6,95 & 81,54 & 81,35 & 8,11 & 8,09 \\
\hline
\end{tabular}

a s: strong; m: médium; sh: shoulder

${ }^{\mathrm{b}} \mathrm{u}_{\mathrm{sym}}\left(\mathrm{COO}^{-}\right)$and $\mathrm{u}_{\mathrm{as}}\left(\mathrm{COO}^{-}\right)$: symmetrical and anti-symmetrical vibrations of the $\mathrm{COO}^{-}$group, respectively

${ }^{c} \tilde{\mathrm{o}}_{\mathrm{as}}^{\mathrm{sym}}\left(\mathrm{COO}^{-}\right)(\mathrm{Na}$ salt $)-\tilde{\mathrm{o}}_{\mathrm{as}}\left(\mathrm{COO}^{-}\right)($metal complex $)$

${ }^{\mathrm{d}}$ Ketonic carbonyl stretching frequency

e $\tilde{\mathrm{o}}(\mathrm{C}=\mathrm{O})($ metal complex $)-\tilde{\mathrm{o}}(\mathrm{C}=\mathrm{O})(\mathrm{Na}$ salt $)$

For the aluminium, gallium and indium compounds, the anti-symmetrical stretching carboxylate frequency is shifted to lower values, while the ketonic carbonyl stretching is shifted to higher values, namely $1589-1595 \mathrm{~cm}^{-1}$ and $1753-1758 \mathrm{~cm}^{-}$ ${ }^{1}$, respectively, relative to the corresponding frequencies in 4-Me-BP (sodium salt). This behavior suggests that the coordination of these compounds occurs by the carboxilate, without participation of the ketonic carbonyl groups of the ligand.

Simultaneous TG-DTA and TG/DTG curves of the compounds are shown in Fig. 1-4. These curves exhibit mass losses in three consecutive and/or overlapping steps, and thermal events corresponding to these losses. These curves also show that the first mass loss for all the compounds occurs within the same temperature range (40$130^{\circ} \mathrm{C}$ ); the second mass loss also begins at the same temperature $\left(130^{\circ} \mathrm{C}\right)$, showing that the thermal behavior up to this step is not dependent on the nature of the metal ion. However, the features shown by the last step of thermal decomposition as well as the mass lost in each step are characteristic of each compound, and no depend on the metal ion present.

For all the compounds, the first mass loss associated to endothermic peak is ascribed to the dehydration, which occurs in a single step and through a slow process. This behavior was also observed during the dehydration of lanthanides and yttrium compounds with other phenyl-substituted derivatives of benzylidenepyruvate, and it seems to be characteristic of compounds obtained in amorphous state $[6,7,12]$.
For the aluminium compound the TG-DTA and TG/DTG curves are shown in Fig 1. The first mass loss observed between $40-130^{\circ} \mathrm{C}$ corresponding to an endothermic peak at $100^{\circ} \mathrm{C}$ is due to hydration water, with loss of $2 \mathrm{H}_{2} \mathrm{O}(\mathrm{Calcd}$. = $5.72 \%$; TG 5.57\%). The thermal decomposition of the anhydrous compound occurs in two steps between $130-410^{\circ} \mathrm{C}$ and $410-530^{\circ} \mathrm{C}$, with losses of $40.28 \%$ and $46.03 \%$ respectively, corresponding to small exothermic event at $378^{\circ} \mathrm{C}$ and a sharp exothermic peak at $518^{\circ} \mathrm{C}$, which are attributed to oxidation of the organic matter. The total mass loss up to $530^{\circ} \mathrm{C}$ is in agreement with the formation of aluminium oxide, $\mathrm{Al}_{2} \mathrm{O}_{3}$, as final residue $(\mathrm{Calcd}$. $=$ $86.20 \%$; $\mathrm{TG}=86.31 \%$ ) and confirmed by X-ray powder diffractometry.

For the gallium compound, the TG-DTA and TG/DTG curves are shown in Fig. 2. The first mass loss, observed between $40-130^{\circ} \mathrm{C}$, corresponding to an endothermic peak at $100^{\circ} \mathrm{C}$ is due to dehydration with loss of $2 \mathrm{H}_{2} \mathrm{O}$ (Calcd. $=5.53 \%$; $\mathrm{TG}=5.51 \%$ ). The thermal decomposition of the anhydrous compound occurs in two steps between $130-410^{\circ} \mathrm{C}$ and $410-480^{\circ} \mathrm{C}$, with losses of $44.24 \% \%$ and $36.51 \%$ respectively, corresponding to small exothermic event at $285^{\circ} \mathrm{C}$ and a sharp exothermic peak at $455^{\circ} \mathrm{C}$, attributed to oxidation of the organic matter. The profiles of the TG-DTA curves for the last mass loss show that the oxidation of the organic matter is accompanied by combustion. The total mass loss up to $480^{\circ} \mathrm{C}$ is in agreement with the formation of gallium oxide, $\mathrm{Ga}_{2} \mathrm{O}_{3}$, as final residue (Calcd. $=80.73 \%$; $\mathrm{TG}=80.75 \%)$ and confirmed by $\mathrm{X}$-ray powder diffractometry. 

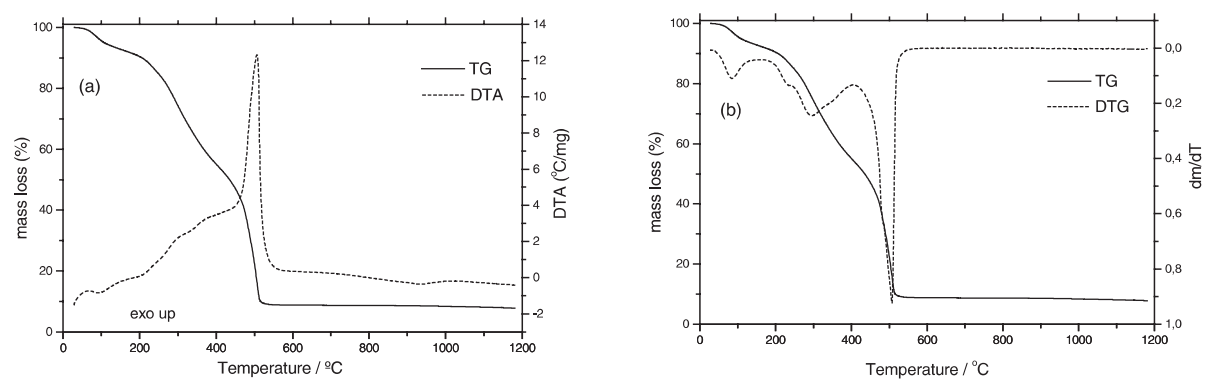

Figure 1. TG-DTA (a) and TG/DTG (b) curves of the Al(4-Me-BP $)_{3} \cdot 2 \mathrm{H}_{2} \mathrm{O}(\mathrm{m}=4.025 \mathrm{mg})$
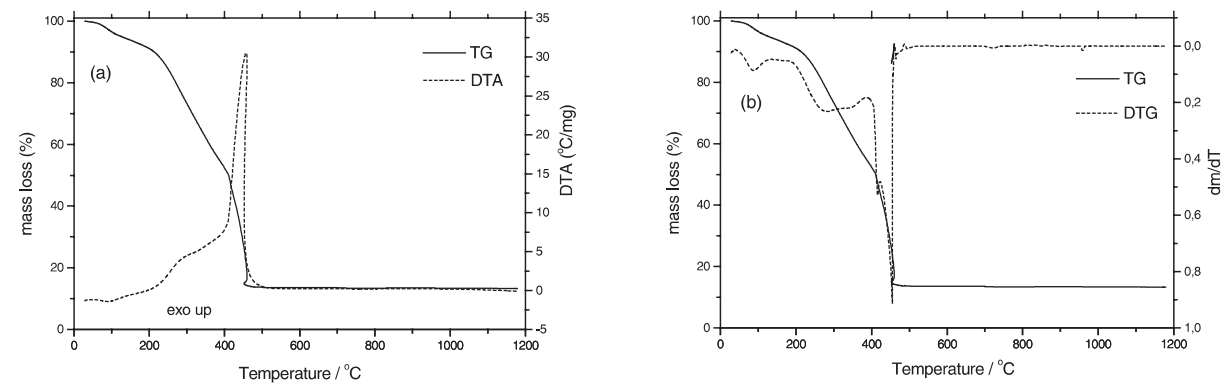

Figure 2. TG-DTA(a) and TG/DTG(a) curves of the Ga(4-Me-BP) $)_{3} \cdot 2 \mathrm{H}_{2} \mathrm{O}(\mathrm{m}=7.884 \mathrm{mg})$
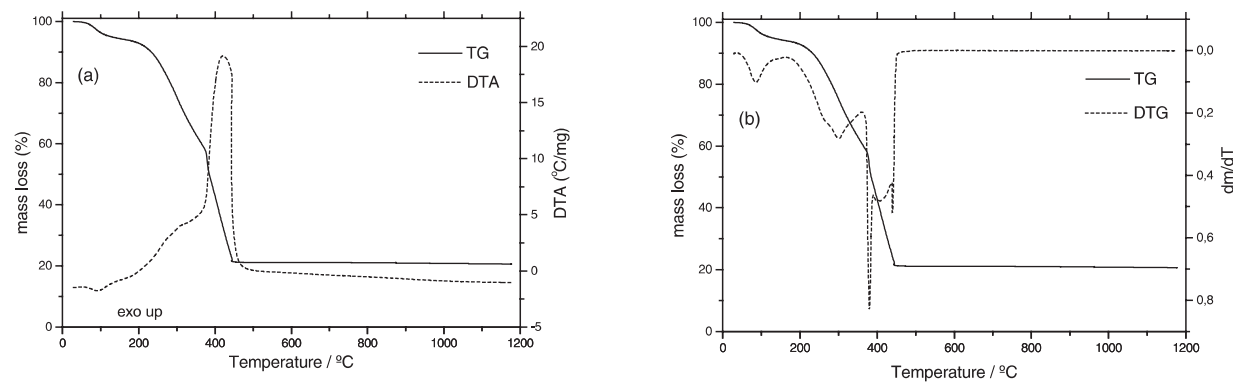

Figure 3. TG-DTA (a) and TG/DTG (b) curves of the $\mathrm{In}(4-\mathrm{Me}-\mathrm{BP})_{3} \cdot 2 \mathrm{H}_{2} \mathrm{O}(\mathrm{m}=6.9031 \mathrm{mg})$
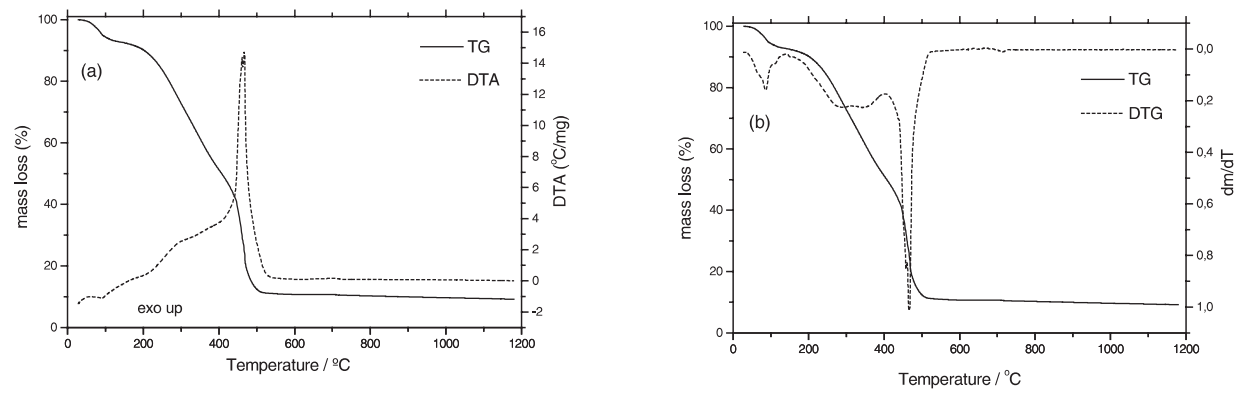

Figure 4. TG-DTA (a) and TG/DTG (b) curves of the $\mathrm{Sc}(4-\mathrm{Me}-\mathrm{BP})_{3} \cdot 3 \mathrm{H}_{2} \mathrm{O}(\mathrm{m}=4.0334 \mathrm{mg})$ 
For the indium compound, the TG-DTA and TG/DTG curves are shown in Fig. 3. The first mass loss that occur between $40-130^{\circ} \mathrm{C}$, corresponding to an endothermic peak at $100^{\circ} \mathrm{C}$ is due to dehydration with loss of $2 \mathrm{H}_{2} \mathrm{O}$ (Calcd. $=5.02 \%$; $\mathrm{TG}=5.12 \%)$. The thermal decomposition of the anhydrous compound also occurs in two steps between $130-370^{\circ} \mathrm{C}$ and $370-450^{\circ} \mathrm{C}$, with losses of $37.47 \% \%$ and $38.19 \%$ respectively, corresponding to small exothermic event at $300^{\circ} \mathrm{C}$ and a large exothermic peak at $425^{\circ} \mathrm{C}$, attributed to oxidation of the organic matter. The profile of the TG-DTA curves for the last mass loss also shows that the oxidation of the organic matter is accompanied by combustion. The total mass loss up to $450^{\circ} \mathrm{C}$ is in agreement with the formation of indium oxide, $\operatorname{In}_{2} \mathrm{O}_{3}$, as final residue $($ Calcd. $=74.93 \%$; $\mathrm{TG}=75.66 \%$ ) and confirmed by X-ray powder diffractometry.

For the scandium compound, the TG-DTA and TG/DTG curves are shown in Fig. 4. The first mass loss, observed between $40-130^{\circ} \mathrm{C}$, corresponding to an endothermic peak at $100^{\circ} \mathrm{C}$ is due to dehydration with loss of $3 \mathrm{H}_{2} \mathrm{O}($ Calcd. $=8.11 \% ; \mathrm{TG}=8.09 \%)$. The thermal decomposition of the anhydrous compound occurs in two steps between $130-420^{\circ} \mathrm{C}$ and 420 $540^{\circ} \mathrm{C}$, with losses of $44.50 \% \%$ and $36.85 \%$ respectively, corresponding to small exothermic event at $300^{\circ} \mathrm{C}$ and a sharp exothermic peak at $465^{\circ} \mathrm{C}$, attributed to oxidation of the organic matter. The total mass loss up to $540^{\circ} \mathrm{C}$ is in agreement with the formation of scandium oxide, $\mathrm{Sc}_{2} \mathrm{O}_{3}$, as final residue (Calcd. = $81.54 \%$; $\mathrm{TG}=81.35 \%$ ) and confirmed by $\mathrm{X}$-ray powder diffractometry.

\section{Conclusions}

From the TG curves and complexometry data, a general formula could be established for these compounds in the solid state. The X-ray powder patterns showed that all the compounds were obtained in amorphous state.

The infrared spectroscopic data suggest that 4-Me-BP acts as a bidentate ligand only for the scandium ion and as a monodentate ligand for aluminium, gallium and indium ions.

The TG-DTA curves provided previously unreported information about the thermal stability and thermal decomposition of these compounds.

\section{Acknowledgements}

The authors thank FAPESP and CNPq Foundations (Brazil) for financial support.

Recebido em: 17/02/2005

Aceito em: 08/03/2005

R. A. Mendes, G. Bannach, E. Y. Ionashiro. Síntese, caracterização e estudos térmicos dos 4metilbenzalpiruvatos de alguns íons metálicos trivalentes no estado sólido.

Resumo: Os 4-metilbenzalpiruvatos de Al(III), Ga(III), In(III) e SC(III), foram sintetizados no estado sólido. Na caracterização e estudo do comportamento térmico desses compostos foram utilizados a complexometria, difratometria de raios X pelo método do pó, espectroscopia na região do infravermelho e termorgravimetriaanálise térmica diferencial simultâneas (TG-DTA). Os resultados forneceram informações com respeito a estequiometria, cristalinidade, estabilidade e decomposição térmica desses compostos.

Palavras-chave: 4-metilbenzalpiruvatos, alumínio, gálio, índio, escândio, comportamento térmico.

\section{References}

[1] C.B. Melios, V.R. Torres, M.H.A. Mota, J.O. Tognolli, M. Molina, Analyst 109 (1984) 385.

[2] C.B. Melios, J.T.S. Campos, M.A.C. Mazzeu, L.L. Campos, M. Molina, J.O. Tognolli, Inorg. Chim. Acta 139 (1987) 163.
[3] C.B. Melios, H. Redigolo, M. Molina, J. Inorg. Biochem. 36 (1989) 307.

[4] C.B. Melios, M. Ionashiro, H. Redigolo, M.H. Miyano, M. Molina, Eur. J. Solid State Inorg. Chem. 28 (1981) 291. 
[5] R.N. Marques, C.B. Melios, N.C.S. Pereira, O.S. Siqueira, M. de Moraes, M. Molina,M. Ionashiro, J. Alloys Comps. 249 (1997) 102.

[6] L.C.S. Oliveira, C.B. Melios, C.A. Ribeiro, M.S. Crespi, M. Ionashiro, Thermochim. Acta 219 (1993) 215.

[7] M.H. Miyano, C.B. Melios, C.A. Ribeiro, H. Redigolo, M. Ionashiro, Thermochim. Acta 221 (1993) 53.

[8] D.E. Rasera, L.C.S. Oliveira, C.B. Melios, M. Ionashiro, Thermochim. Acta 250 (1995) 151.

[9] L.C.S Oliveira, D.E. Rasera, O.S. Siqueira, J. R. Matos, C. B. Melios, M. Ionashiro, Thermochim. Acta 275 (1996) 269. [10] L.C.S. Oliveira, D.E. Rasera, J.D.S. Oliveira, C.B. Melios, M. Ionashiro, An. Assoc. Bras. Quím. 47 (1998) 75.

[11] R. A. Mendes, M.A.S. Carvalho Filho, N. S. Fernandes, L. M. D'Assunção, C.B. Melios, M. Ionashiro, An. Assoc. Bras. Quím. 47 (1998) 329.

[12] N. S. Fernandes, M.A.S. Carvalho Filho, C.B. Melios, M. Ionashiro, J. Thermal Anal. Cal. 59 (2000) 663.
[13] R.N. Marques, C.B. Melios, M. Ionashiro. Thermochim. Acta 395 (2003) 145-150.

[14] C. Melios, A.M. Delsin, J.O. Tognolli, M. Molina, Ecl. Quim. 6 (1981) 51.

[15] J. Kinnumen and B. Wennerstrand, Chemist. Analyst, 46, 4 (1957) 92.

[16] G. H. Jeffery, J. Basset, J. Mendham, R.C. Denney, VOGEL, Análise Química Quantitativa, Quinta edição, Guanabara Koogan, RJ, 1988, pp.266.

[17] G. Sócrates, Infrared Characteristic Group Frequencies, 2nd ed. Wiley, New York, 1994, pp.91 and 236-7.

[18] R.M. Silverstein, F.X. Webster, Spectrometric Identification of Organic Compounds, $6^{\text {th }}$ ed., Wiley, New York, 1998, pp. 92, 93, 96 and 97.

[19] F.A. Cotton, in: J. Lewis, R.G. Wilkins (Eds.), The Infrared Spectra of Transition Metal Complexes in Modern Coordenation Chemistry, Interscience, New York, 1960, pp. 379-386. 